\title{
THE STRATEGY OF TRAFFIC POLICE TO INTERCEPT VEHICLE USED BY UNDERAGE STUDENTS IN KEDIRI SECTOR POLICE JURISDICTION
}

\author{
Danuardi Probandono Bobby* \\ Postgraduate School, University of Airlangga, Indonesia \\ E-mail: bobbydanuardi@ymail.com
}

\begin{abstract}
The development of the era makes the younger generation has a lot of expertise in all fields, but on the other hand many of the younger generation who do social deviation. One of them is riding a motorcycle by a child under age. This study aims to determine the level of vehicle use by underage children, factors influencing vehicle use by underage children and to analyze the Traffic Police strategy in preventing the level of motor vehicle usage by children underage in the Kediri Police area. The results of the study indicate that there is an increase in the number of underage child riders, especially in Junior High School and Senior High School students in Kediri Police area. Factors of motor vehicle usage by underage children are internal factors and external factors. Policies strategy in preventing the level of motor vehicle usage by students in jurisdiction of Kediri Police, that is by preventive and repressive effort.
\end{abstract}

\section{KEY WORDS}

Traffic, child, rider, motor vehicle, student.

The highway transportation, as one of modes of transportation, is the most strategic and important infrastructure, within the increasing number of people mobility either to carry commodities or service across vast areas.

Thus, there is significant system to regulate this phenomenon which is developed into traffic rules by integrating and increasing the dynamic elements of traffic itself. The elements consist of street transportation web, the vehicles and its drivers, traffics, procedures and the methods which will result in solid system within excellent result used by vast societies. Because, the societies need high mobility to do their daily live business such as going to the workplace, school, groceries, and other social activities.

Eventually, transportation is the most vital and strategic infrastructure to run the wheel of economics, consolidate the unity among people, and affect all aspects of a nation. Whereas, this transporting activities are used by wide societies including children and adult, from the old to the youth, men or women.

Unfortunately, there are many traffic violations nowadays. The violations are dominated by motorcyclist as it is the number one population of vehicles used by Indonesian people compared with another vehicle. In total, the motorcyclists are responsible for $70 \%$ traffic accidents across the nation. Right now, it increases into $80 \%$ of total traffic accidents.

There are many factors that caused traffic accidents. Most of them are the result of human errors, because the level of awareness and obeying traffic rules is still low. In a certain age, especially in teenage phase, the emotional condition of somebody is so fragile to do arrogant action on the road. As a result, they will not pay attention to the safety of other drivers and it decreases the level of concentration of the driver itself.

Motorcycle is the most favourite vehicles in Indonesia. Someone who ride a motorcycle is called a rider. The rider is someone who operates the vehicle or someone who directly watch the driver skill while driving for the first time both motored or not. The increasing number of people who die in traffic accidents rises a new term that road is the most number one killer in Indonesia. In fact, even though the rules to intercept the riders violating traffics had been implemented, there is still numerous violations. Ironically, the government, who is responsible to prevent he underage students to ride motorcycle, does not give full attention to this phenomenon. 
The youth is the next generation that must grow and develop to continue the existence of a nation, thus everybody is responsible to guide them to earn good characteristics, and determine their identity accordance with their growing golden age. This makes the youth possessed strategic position in the development of a nation. The rapid growth in globalisation tend to make children learn many skills in no time, but it also makes them inconvenient about the social aspects. One of it is by riding the motorcycle.

The underage motorcycle riding is considered as youth delinquency and mistaken as they do not have the riding license nor they are ready to ride the motorcycle, yet. Most of societies assume that underage motorcycle riding is a common phenomenon because it is still of what they called as normal use. But, because the age of them is still not old enough, they will have a potential to harm other riders because they are not yet able to control their self. The good riders are those who obey the traffic rules or the current regulation to avoid disadvantage from both riders and another rider.

Moreover, this phenomenon, which has been clarified as common event by societies, earns full supports from the parents by providing their children with motorcycles. By bluffing thousand reasons, they do not realise that the age of their children is still considered as underage by the law. Surprisingly, the parents feel so much pride when their under ages are able to ride motorcycles or drive cars while they are still on elementary or junior high school. The condition motivates the increasing number of vehicle using among under ages.

The increasing number of vehicle use by under ages triggers the traffic police department to do their duties and responsibilities correctly. Moreover, the law number 22 of 2009 about traffic rule and carrier transportation could be a guidance for police as one of legal institution that responsible to socialise and illuminates people about the importance of traffic rules.

Traffic police must demonstrate their strategies in overcoming and preventing the use of motor vehicles by under ages. A strategy is a set of managerial decisions and actions that determine the company's performance over the long term. Research conducted by Mattias Mauriz Tarigan (2014) shows that the strategy of the traffic police in preventing underage from driving on a public road is to carry out the police function through 2 actions: a) preventive action, with all kinds of precautions; and b) repressive measures, are actions taken to enforce traffic laws in the event of a violation on the road. But in practice, there are constraints in which there is a choice of sanctions between confinement and fines. Most of the people and minors who commit motor vehicle violations prefer to pay a fine so as not to have a deterrent effect on offenders and police who are considered enemies by minors due to lack of knowledge and understanding of the laws applicable in Street.

\section{METHODS OF RESEARCH}

This study uses descriptive qualitative which takes its setting in Kediri Resort Police jurisdiction. Because, there are so many traffic violation cases by the underage found in this area. This becomes major concentration as the police should be able to guarantee the safety of society from dangerous aspects including the students.

\section{RESULTS AND DISCUSSION}

The level and factor of vehicle using by underage students in Kediri resort police jurisdiction. It has been found relatively a lot of underage motorist, especially in children Junior High School (SMP) and High School (SMA). Based on the data of child perpetrators from Kediri Police, the perpetrator of accidents by minors for three years is 2015-2017 period amounting to 1.259 , where the actors with the level of primary education as many as 241 children, junior numbered 328, and high school totaling 690 children. This is certainly an indication that the number of accidents, whether caused or cause of child victims should be a special attention for the Police Kediri. Underage motorist must be noticed by parents, so as not carelessly given a motorcycle license because it can endanger themselves and others. 
The factor of vehicle using by underage students in Kediri resort police jurisdiction. In fact, the violation commenced by underage is not based on their evil will/evil mind, but it is more to be deviation of social norms. The child experts agreed that the term for this case is brat or Juvenale Delinquency. By using the term, the experts expect society not to include the children into criminal category. There are several factors that cause traffic violation by the children, as follow.

Internal Factor:

- The Immature Emotion Factor. Teenagers are known as time of finding that you are process. Their emotions become unpredictable as a result of physical and hormonal change. Thus, it needs a new self-control of their self. In this state, they become unconscious, unpredictable, and do harassment actions to cover their weakness or to increase their self-confident. The rage leads them to be intolerant to others and become arrogance/stubborn. They start to observe their teachers and friends objectively. In adolescents aged 15-18 years, adolescent rebellion is a universal expression and change from childhood to adulthood. In general, the parents provide their children with motor vehicle to get to school. Because, the parents are afraid of the criminality and safety of their children in public transportation. But, they do not aware of the discipline by letting their underage kids riding the motorcycle in highway. Another way to solve this problem is by using school bus to provide comfort and safety for both parents and children.

- Parenting pattern. Parenting is a series of forms or ordinances performed by parents in maintaining, nurturing and educating their children are consistent which is manifested in the form of interaction between parents and children. The underage riders are commonly found in village and city. Nowadays, the kids villager become has been grown braver to violates the traffics. But, the parents' omission construct social paradigm that turn this bad behaviour into a common culture. It is must be prevented as it will trigger other people to duplicate the action. Eventually, the number of underage riders will be increasing. Moreover, the low self-awareness capability of the young riders causes many traffic accidents.

External Factor:

- Environment Factor. The most capable external factor that causes this phenomenon is the environment. Wherever the students take place, if the environment supports them to ride motorcycle, they will use it as well as other children. Even though the parents who are already forbid their kids to ride motorcycle, eventually, the parents gave up and let their children to ride it as they always make a demand for the parents to be the same with other cool kids.

- Friends Factor. Another factor that causes underage to ride motorcycle is their friends. A friend will surely affect the underage behaviours. Moreover, junior high school is a crucial time that they will be easily deceived and affected by others. That is why, in some cases, the underage learn their riding skill from their neighbourhood friends. It proves that the effect of friendship is very strong. Sometimes, the students who do not ride motorcycle to school is called nerds by their friend and does not include in cool kids club as all kids wish to be. It is widely known as millennial trends, nowadays. Most of the underage who demand to ride motorcycle is those who still cannot control their emotions. Even though they are well aware that it is a traffic violation to ride motorcycle without license and not as old as 17 years old, this does not stop their desire to ride.

School Factor. As education infrastructure to study, school holds important role to educate discipline behaviour among youth. Unfortunately, some schools allow their student to ride motorcycle to school. It motivates the student to be more excited to ride their motorcycles. The low rate socialisation and illumination form police department causes the phenomenon to be overbalance.

The Strategy of Traffic Police to Intercept the Number of Vehicle Using By Underage Students in Kediri Sector Police Jurisdiction. 
Preventive Action. By implementing safety riding program, the police traffic applied their socialisation by spreading the brochure of safe riding awareness. The brochure was distributed to settlements or regencies or in public places of Kediri where the youth love to gather. Commencing traffic education for some students to several schools such as senior high school $r$ vocational high school

Repressive Action. in repressive action, to intercept the traffic violation by the riders or the drivers, ticket penalizing is the most effective way to judge the under age students, their motorcycle is taken to police office. The vehicle will be returned as the parents of the students accommodate the administration and receive some counselling from the police department.

\section{CONCLUSION AND SUGGESTIONS}

From the explanations of previous chapter above, the conclusions will be, as follow:

There is a significance increase of vehicle using by underage that mostly come from junior and senior high school student in Kediri Resort Police jurisdiction.

The factor that motivates underage to ride motorcycle consists of internal and external factors. The internal factors are immature emotion controls and parenting pattern factors. Meanwhile, the external factors consist of environment, friends, and school factors.

The strategy of traffic police to intercept the number of vehicle using by underage students in Kediri sector police jurisdiction are preventive and repressive attempts. The preventive attempts are done by distributing awareness brochure to some public are. While, the repressive actions are using ticket to penalise the underage motorcyclist, their motorcycle is taken to police office. The vehicle will be returned as the parents of the students accommodate the administration and receive some counselling from the police department.

According to the conclusions above, the writer would love to suggest several points, as follow:

- To the parents. The parent must support the government to prioritise the safety riding program by not providing thei children with motorcycle. Instead of following the live style trend or to shorten time for their children to get to school, the underage is best to afford public transportation or by picking them up in school.

- To the School. The school could initiate to include traffic education in their curricula. It also could cooperate with police department to hold traffic awareness socialisation.

- To Human Resource and Social Illumination Department of Kediri Resort Police. By improving the synergy between teachers and police officers to increase the awareness to the parents about the dangerous decision letting their children to ride motorcycle. Eventually, the parents will well aware of their duties to accompany and pick their children to school. Moreover, the parents could afford their children with bicycle or public transportation instead of providing them with motorcycle as it against the law.

\section{REFERENCES}

1. Aroma, Iga Serpianing dan Dewi Retno Suminar. 2012. Hubungan Antara Tingkat Kontrol Diri Dengan Kecenderungan Perilaku Kenakalan Remaja. Jurnal Psikologi Pendidikan dan Perkembangan, Vol. 1, No. 2, Juni, hal. 1-6.

2. Creswell, John W. 2013.Research Design Pendekatan Kualitatif, Kuantitatif, dan Mixed.Yogyakarta: Pustaka Pelajar.

3. Gumarso, Singgih D.,1988. Psikologi Perkembangan Anak dan Remaja. Jakarta: Gunung Mulia.

4. Hamidi. 2010. Metode Penelitian dan Teori Komunikasi. Malang: Universitas Muhammadiyah Malang Press.

5. Joao Mario Freitas, Muhammad Yusuf, Petrus Wisnubroto. 2013. Strategi Pemasaran Guna Meningkatan Volume Penjualan Dengan Pendekatan Technology Atlas Project Method. Jurnal REKAVASI, Vol. 1. No. 1, hal. 30-37. 
6. Kartini-Kartono.1989.Psikologi Anak (Psikologi Perkembangan). Bandung: Mandar Maju.

7. Marshall and Roosman. 2007. Designing Qualitative Research. London: Sage Publication.

8. Moleong, Lexy J. 2007. Metodologi Penelitian Kualitatif. Bandung: Remaja Rosdakary.

9. Notoatmodjo, S. 2003. Metodologi Penelitian Kesehatan. Jakarta: Rineka Cipta.

10. Permatasari,Anggalia Putri. 2011. Konsep Strategi dan Kebijakan Penanggulangan Terorisme di Indoenesia. Jurnal Kajian Terorisme dalam Keamanan Internasional Departemen IImu Hubungan Internasional. FISIP UI. Hal. 1-25.

11. Primulyani, A. N. 2011. Fenomena Pengendara Motor di Bawah umur di Jalan Kesatrian Kidul Kota Magelang.

12. Rosita Saragih. Gambaran Perilaku Masyarakat Tentang Pelayanan Puskesmas di Desa Sukaraya Kecamatan Pancur Batu Kabupaten Deli Serdang. Jurnal Darma Agung, 2010.

13. Saragih, R. 2010. Gambaran Perilaku Masyarakat Tentang Pelayanan Puskesmas di Desa Sukaraya Kecamatan Pancur Batu Kabupaten Deli Serdang. Jurnal Darma Agung.

14. Sari, Dewi Anjar. 2015. Konseling Melalui Media Telekomunikasi Telepon (Studi Kasus di Tesa 129 Pusat Pelayanan Terpadu Perempuan dan Anak "Rekso Dyah Utami" Daerah Istimewa Yogyakarta). Jurnal Komunikasi Universitas Islam Negeri Sunan Kalijaga Yogyakarta.

15. Setiawan, Jerry. 2014. Latar Belakang Perilaku Remaja Dalam Mengemudikan Sepeda Motor Tanpa Surat Izin Mengemudi (Studi Kasus Pelajar SMPN 11 Kota Samarinda).eJournal IImu Sosiatri. hal. 1-15.

16. Simamora, B.2008.Panduan Riset Perilaku Konsumen. Jakarta: Gramedia.

17. Suryabrata, S. 1993. Psikologi Perkembangan. Jakarta: Raja Grafika Persada.

18. Suryani,Yuni.,Holilullaoh dan Yunisca Nurmalisa. 2014. Sikap Orang Tua Terhadap Pengendara Motor dibawah Umur di Lampun Selatan. Jurnal Psikologi Pendidikan Lampung Selatan, hal. 1-12.

19. Tarigan, Mattias Mauriz. 2014. Peran Polisi dalam Mencegah Anak di Bawah Umur Mengendarai Kendaraan Bermotor di Jalan Umum Daerah Istimewa Yogyakarta.

20. Soejono dan Abdurrahman.2005.Metode Penelitian Kualitatif. Gramedia Pustaka Utama.

21. Yusuf. 2006. Psikologi Perkembangan Anak \& Remaja. Bandung: ROSDA. 